ZOOLOGIA 30 (1): 49-54, February, 2013

http://dx.doi.org/10.1590/S1984-46702013000100006

\title{
Assessing the efficacy of hair snares as a method for noninvasive sampling of Neotropical felids
}

\author{
Tatiana P. Portella1,2,4, Diego R. Bilski², Fernando C. Passos ${ }^{3} \&$ Marcio R. Pie $^{1}$ \\ 1 Laboratório de Dinâmica Evolutiva e Sistemas Complexos, Departamento de Zoologia, Universidade Federal do Paraná. \\ Caixa Postal 19020, 81531-990 Curitiba, PR, Brazil. \\ 2 Programa de Pós-Graduação em Ecologia e Conservação, Universidade Federal do Paraná. \\ ${ }^{3}$ Laboratório de Biodiversidade, Conservação e Ecologia de Animais Silvestres, Departamento de Zoologia, Universidade \\ Federal do Paraná. Caixa Postal 19020, 81531-990 Curitiba, PR, Brazil. \\ ${ }^{4}$ Corresponding author. E-mail: portellatp@yahoo.com.br
}

\begin{abstract}
Hair snares have been used in North and Central America for a long time in assessment and monitoring studies of several mammalian species. This method can provide a cheap, suitable, and efficient way to monitor mammals because it combines characteristics that are not present in most alternative techniques. However, despite their usefulness, hair snares are rarely used in other parts of the world. The aim of our study was to evaluate the effectiveness of hair snares and three scent lures (cinnamon, catnip, and vanilla) in the detection of felids in one of the largest remnants of the Brazilian Atlantic Forest. We performed tests with six captive felid species - Panthera onca (Linnaeus, 1758), Leopardus pardalis (Linnaeus, 1758), L. tigrinus (Schreber, 1775), L. wiedii (Schinz, 1821), Puma concolor (Linnaeus, 1771), and P. yagouaroundi (É. Geoffroy Saint-Hilaire, 1803) - to examine their responses to the attractants, and to correlate those with lure efficiency in the field. The field tests were conducted at the Parque Estadual Pico do Marumbi, state of Paraná, Brazil. Hair traps were placed on seven transects. There were equal numbers of traps with each scent lure, for a total of 1,551 trap-days. In captivity, vanilla provided the greatest response, yet no felids were detected in the field with any of the tested lures, although other species were recorded. Based on the sampling of non-target species, and the comparison with similar studies elsewhere, this study points to a possible caveat of this method when rare species or small populations are concerned. Meanwhile, we believe that improved hair snares could provide important results with several species in the location tested and others.
\end{abstract}

KEY WORDS. Atlantic Forest; detection technique; hair; scent lure; rubbing behavior.

Of all 37 recognized wild felid species, eight can be found in Brazil. All of them are placed in the threatened category in regional (BRESSAN et al. 2009, BRAGA \& Vidolin 2010), national (MACHADO et al. 2008) or international (IUCN 2011) official lists. Habitat loss and poaching are considered to be the major threats to these animals, (Machado et al. 2008) and the lack of knowledge about their behavior, basic biology and distribution (Oliveira 2006) is a threat to their conservation in the future.

Due to their secretive behavior, low densities and predominantly crepuscular and/or night habits, the observation and capture of wild felids can be very expensive and require a considerable effort (Tomas et al. 2006, Aguiar \& Moro-Rios 2009). As a consequence, non-invasive methods and indirect evidence such as scats, tracks, camera-traps, and hair-traps are often used to study felids (Long et al. 2008). Feces can be used in dietary and molecular analyses (Miranda et al. 2005, Ludwig et al. 2007, Miotto et al. 2007, Heinemeyer et al. 2008, Silva-Pereira et al. 2011). However, finding scats in the field can be harder in humid and montane forests, where frequent rains over an irregular landscape can remove feces from trails, where they are more easily found (Crawshaw et al. 1997). Tracks can be used to monitor felids, but the correct discrimination between tracks of small felids is difficult (BECKER \& DALPONTE 1999). Automatic cameratraps can provide reliable identifications, but these devices are relatively expensive for developing countries, and several models cannot handle the high humidity of tropical forests. Hairtraps, on the other hand, represent a cheaper alternative, and are less affected by the weather. The identification of the species can be done through microscopic analysis of the cuticle patterns of the guard hairs or through DNA analysis (WEAVER et al. 2005, Kendall \& McKelvey 2008). Moreover, passive methods such as camera-traps and hair snares can be installed in sites of difficult access, thus minimizing the possible bias in the area covered, a pitfall of other methods (WASSER et al. 2004).

There are several kinds of hair-traps, developed according to the target species or group (Kendall \& McKelvey 2008). 
The most common snares used for felids consist of a rigid plate covered with short-napped carpet or hook-and-loop fasteners (e.g. Velcro ${ }^{\mathrm{TM}}$ ), and wires or nails attached to the carpet (WEAVER et al. 2005). These plates are used by the felids in their natural cheek-rubbing behavior, during which some hairs are snagged. However, in order to work properly, this method requires scented lures that attract the species, and also elicit the rubbing behavior (McDaniel et al. 2000, Weaver et al. 2005, Kendall $\&$ McKelvey 2008). The effectiveness of lures and snares varies among species, individuals and even among study sites (Harrison 1997, Thomas et al. 2005, Castro-Arellano et al. 2008, Schlexer 2008). For this reason, controlled tests of their efficiency are recommended before they are used in field studies (SCHLEXER 2008). Multiple studies have evaluated the efficacy of hair-snares with several lures on the Nearctic region (WEAVER et al. 2005, Bertrand et al. 2006, McKelvey et al. 2006, Long et al. 2007, Ruell \& Crooks 2007) and in Central America (Harrison 1997, Downey et al. 2007, CASTro-Arellano et al. 2008), but there are no published studies in South America. Therefore, the main objective of our study was to evaluate the effectiveness of three scent lures to attract six Neotropical felid species to hair snares, in one of the largest Atlantic Forest remnants in South America.

\section{MATERIAL AND METHODS}

Catnip (Nepeta cataria, Lamiaceae), cinnamon, and vanilla were chosen as potential attractant scents. Catnip is commonly employed in this type of study (HaRrison 1997, MCDANIEL et al. 2000, CASTro-Arellano et al. 2008, Schlexer 2008), and cinnamon was successfully used by Niara Martins (per. comm.) to detect pumas, Puma concolor (Linnaeus, 1771), in a cerrado region of the Estação Ecológica do Jataí, Brazil. We found no previous studies that employed vanilla as a scent lure, but it proved to be effective in stimulating rubbing behavior in tests that we performed with captive felids.

How efficient these scents are in stimulating the rubbing behavior, and the capacity of the hair-snare to remove hairs were evaluated with captive felids using a methodology similar to that of HARRISON (1997). Using this test, we can assess the intensity of the interactions in captivity, and potentially associate them with the rate of detection of wild animals. The behavioral responses of ten ocelots, Leopardus pardalis (Linnaeus, 1758), seven margays, Leopardus wiedii (Schinz, 1821), six oncillas, Leopardus tigrinus (Schreber, 1775), six pumas, five jaguaroundis, Puma yagouaroundi (É Geoffroy Saint-Hilaire, 1803), and five jaguars, Panthera onca (Linnaeus, 1758) were evaluated, for all the three scents. To evaluate their responses, we provided, to each individual in an enclosure, wooden blocks sprayed with one of the lures, and then observed the animals for one hour, to record the occurrence and duration of the rubbing behavior. The total amount of time the animal spent rubbing on the block was used as a proxy for the efficiency of the lure. All scent lures were provided for all species and individu- als, on different days, and the choice of the lure used was defined randomly. As a negative control, we repeated the tests providing only the wooden blocks with no lures. The non-parametric Friedman test was used to evaluate if there was a difference between interactions with each lure for each species. When significant differences occurred, Wilcoxon tests were used to compare the pairs.

Field tests were conducted in the Parque Estadual Pico do Marumbi (PEPM), state of Paraná, southern Brazil. This park has an area of more than 8,000 ha, located within the AEIT (Área de Especial Interesse Turístico) of Marumbi, an area of $66,732.99$ ha of continuous Atlantic Ombrophylous Dense Forest, comprising low-slope, montane and high montane forests (MARQues et al. 2011). In accord with Köppen's climate classification, the climate at the PEPM can be classified as Cfb with cool summers and precipitation in all seasons (SEMA-IAP 1996). Field campaigns were conducted on July and August of 2009, and from April through July of 2010. We used hair-snare mobile stations like those described by Downey et al. (2007) in seven transects of varying lengths, with three, six, nine or 12 snares per transect, comprising a total effort of 1,551 trap-days. Along each transect we deployed the same number of snares with each scent lure, evenly spaced, and revisited these sites after five or six nights, thus relocating the snares. The seven transects were never sampled consecutively. Hairs recovered from the snares were mounted on glass slides according to Quadros \& Monteiro-Filho (2006), and identified by comparison of the microscopic structure of the cuticular and medullar patterns with those described by Quadros \& Monteiro-Filho (2010). All the species included in the captivity tests occur in the PEPM (Leite \& Galvão 2002, Cáceres 2004).

\section{RESULTS}

In the tests performed in captivity, pumas did not interacted with any of the scent lures. The Friedman tests show significant differences between the scent lures and the negative control for the ocelot $\left(\chi^{2}=16.9, \mathrm{p}=0.0007\right)$, margay $\left(\chi^{2}=\right.$ $9.76, p=0.020)$ and the oncilla $\left(\chi^{2}=8.37, p=0.038\right)$. Based on the Wilcoxon tests results (Table I), the ocelot interacted significantly more with cinnamon and vanilla than with catnip and the negative control, and the margay interacted more with vanilla than with catnip and the control, with no significant difference between the other scents. There were no differences between any pair of scents for the oncilla. Evaluating those species that interacted with at least one scent lure, vanilla can be considered the most effective substance in eliciting the rubbing behavior (Table I).

Hair snares yielded little success in the field tests, with no detection of felid species. Hairs of other mammals were recovered from the snares, including Lontra longicaudis (Olfers, 1818), Cerdocyon thous (Linnaeus, 1766), Procyon cancrivorus (G. Cuvier, 1798), Sapajus nigritus (Goldfuss, 1809), and one species that 
Table I. Results of the Wilcoxon tests comparing pairs of stimulants for those species that had differences indicated by the Friedman test. Cinnamon (Cin), Vanilla (Van), Catnip (Cat), Control (Ctr). $\mathrm{n}=$ number of individuals.

\begin{tabular}{|c|c|c|c|c|c|c|c|c|c|c|c|c|c|}
\hline & \multirow{2}{*}{$n$} & \multicolumn{2}{|c|}{ Cin/Van } & \multicolumn{2}{|c|}{ Cin/Cat } & \multicolumn{2}{|c|}{$\mathrm{Cin} / \mathrm{Ctr}$} & \multicolumn{2}{|c|}{ Van/Cat } & \multicolumn{2}{|c|}{ Van/Ctr } & \multicolumn{2}{|c|}{ Cat/Ctr } \\
\hline & & Z & $\mathrm{p}$ & Z & $\mathrm{p}$ & Z & $p$ & Z & $p$ & Z & $p$ & Z & $\mathrm{p}$ \\
\hline Ocelot & 10 & 1.35 & 0.17 & 2.02 & 0.04 & 2.02 & 0.04 & 2.36 & 0.01 & 2.36 & 0.01 & - & - \\
\hline Margay & 7 & 1.21 & 0.22 & 0.67 & 0.50 & 1.48 & 0.13 & 2.02 & 0.04 & 2.02 & 0.04 & - & - \\
\hline Oncilla & 6 & 1.60 & 0.10 & 1.60 & 0.10 & 1.60 & 0.10 & 1.60 & 0.10 & 1.60 & 0.10 & - & - \\
\hline All species ${ }^{1}$ & 33 & 2.10 & 0.03 & 2.53 & 0.01 & 3.29 & $<0.001$ & 3.54 & $<0.001$ & 3.51 & $<0.001$ & 1.27 & 0.20 \\
\hline
\end{tabular}

${ }^{1}$ excluding Puma concolor.

could not be identified based on QuAdros \& MonTEIro-FiLHO (2010). The respective attractants of these species are presented in Table II. Catnip and cinnamon were the only attractants in the field tests that had any success, while vanilla yielded no records.

Table II. Species recorded on the hair snares on Parque Estadual Pico do Marumbi, and the respective attractants. Cinnamon (Cin), Vanilla (Van), Catnip (Cat), (N) number of occurrences.

\begin{tabular}{|c|c|c|c|c|}
\hline \multirow{2}{*}{ Species } & \multirow{2}{*}{ Common name } & \multicolumn{3}{|c|}{$\mathrm{N}$} \\
\hline & & Cin & Van & Cat \\
\hline \multicolumn{5}{|l|}{ Primates } \\
\hline \multicolumn{5}{|l|}{ Cebidae } \\
\hline Sapajus nigritus & Capuchin monkey & - & - & 1 \\
\hline \multicolumn{5}{|l|}{ Carnivora } \\
\hline \multicolumn{5}{|l|}{ Canidae } \\
\hline Cerdocyon thous & Crab-eating fox & - & - & 1 \\
\hline \multicolumn{5}{|l|}{ Mustelidae } \\
\hline Lontra longicaudis & Otter & 1 & - & - \\
\hline \multicolumn{5}{|l|}{ Procyonidae } \\
\hline Procyon cancrivorous & Crab-eating raccoon & 1 & - & - \\
\hline Unidentified species & & - & - & 1 \\
\hline Total & & 2 & - & 3 \\
\hline
\end{tabular}

\section{DISCUSSION}

Due to the fact that no felid species was detected during our field tests, we could not evaluate the correlation between the intensity of responses in captivity with the efficiency of the scent lures to attract wild felids. In a similar study, HARRISON (1997) also could not make this kind of comparison due to the low success in felid detection. But considering all detected carnivorous species, HARRISON (1997) found a positive association between the intensity of the responses of felids in captivity and the attraction of carnivorous species in the field. On the other hand, in our study vanilla was an ineffective attractant in the field, despite eliciting the strongest responses in the tests with captive felids.
The lack of response by the wild species to the scent lures, in contrast to the prominent interaction of the captive individuals, can be a side effect of the different environmental conditions to which these animals are exposed. According to WeLLER \& BeNNETT (2001), captive animals are often sedentary and less engaged in exploratory behaviors than their wild counterparts, probably due to the lower complexity and higher previsibility of captivity. This can undermine the motivation, opportunity, or the necessity of certain behaviors (McPheE 2002). Because of this lack of stimuli, when new attractants are introduced into the captive environments, they can elicit stronger behavioral responses than those observed in wild animals (TANÁs \& Pisula 2011) or in more complex enclosures. In fact, in our study individuals maintained in less complex enclosures interacted more intensely with the scent lures than those kept in more enriched places (data not shown). By contrast, the captive pumas in our study (some of those maintained in poor enclosures) failed to respond to the stimulants. This is surprising given that this species was detected in the wild by other researchers using catnip (Weaver et al. 2005, Castro-Arellano et al. 2008).

The failure to detect wild felids through hair snares, where they are known to occur, is not uncommon (THomas et al. 2005, Downey et al. 2007, ReEd 2011). As in our study, several researchers had more success detecting generalist carnivores such as some canid, procyonid and ursid species (Harrison 1997, THOmas et al. 2005, Downey et al. 2007, Ruell \& Crooks 2007). These groups are known to have better olfactive acuity than felids (GitTLEMAn 1991), and therefore could be attracted to the snares sooner. According to Downey et al. (2007), felids may avoid rubbing in snares already marked by other species, particularly where these other species occur at high densities. In our study, however, non-target species were seldom detected, and therefore it is unlikely that other species inhibited felid rubbing on the snares. However, even the human odor possibly present on the snares can hinder the approximation of felids (SCHLEXER 2008). Contrary to felids, which are known to avoid human contact (Martins et al. 2008), most of the species detected in our study (with the exception of the otter) are generalist-opportunists, and are acknowledged as being well adapted to anthropic environments (FACURE \& Monteiro-Filho 1996, SABbatini et al. 2008, Aguiar et al. 2011). Although we were care- 
ful when transporting the snares in the field, avoiding unnecessary human contact, we cannot dismiss the possibility of human scents on the snares, given that we did not use gloves or odor removers. Commercial odor removers can be useful to avoid human odor in this kind of study, but they are not necessarily odorless to carnivores, a point that needs to be evaluated prior to their use.

The profitability of hair snares can also be associated with the study site and density of target species. In a study similar to ours, at Estação Ecológica do Jataí, the use of hair snares, with catnip and cinnamon as attractants, recovered a high number of hairs of $P$. concolor (Niara Martins, pers. comm.). A study conducted by Міотто et al. (2011) points to a high density of pumas at the Estação Ecológica do Jataí and surrounding areas, and although no similar studies have been conducted on PEPM, Atlantic Ombrophylous Dense Forests are known to support lower densities of medium and large sized mammals than other formations of the Atlantic Forest (GaletTI et al. 2009). The fact that no felid hairs were recovered in our study can indicate a low density of these animals at the PEPM, and the inefficiency of hair snares in detecting rare species when used for short periods of time.

The low efficiency of this method in detecting species that occurs at low densities becomes evident when we compare the studies performed by Downey et al. (2007) and CASTROArellano et al. (2008), both conducted in El Cielo Biosphere Reserve, Mexico. Downey et al. (2007) had an effort of 1,920 trap-days, and detected only six species, four of those domestic animals, and was unable to detect felids. Using the same transects, but with a total effort of 8,149 trap-days, CASTROArellano et al. (2008) registered 14 wild species, including four felid species. However, despite their success in detecting felids, only the mountain lion was detected more than 10 times. This comparison points to the necessity of great efforts to reliably assess rare species using hair snares.

The design of the trap can equally affect detection success. We designed a hair trap to be disguised in the environment. Felids are more responsive to visual than to olfactive attractants (SCHELEXER 2008), and several studies already used CDs and aluminum plates near the hair snares to visually entice felids (McDaniel et al. 2000, Weaver et al. 2005, Ruell \& Своокs 2007). However, despite being frequently used, no study to date has evaluated the efficiency of visual attractants in improving the efficiency of hair snares, nor attempted to assess a possible negative impact of them. Harrison (1997) and Castro-Arellano et al. (2008) had success using felt cloths hung above the snares, embedded with commercial trapping lures (Carman's Canine Call, Hawbaker's Wildcat lure \#.1, Carman's Raccoon lure \# 1; Minnesota Trapline Products). However, these commercial lures are sold only in North American countries, what hinders their use elsewhere.

Regardless of the lack of success of hair snares in the present study, and the different factors that can affect the outcomes of this method, such as interference from non-target species, low abundance, and difficult attraction of some groups to the snares, we believe that this method is still useful. This technique has been used in North and Central America for the last 20 years (Kendall \& McKelvey 2008), and through continuous improvement it has contributed in wildlife assessments (CASTro-Arellano et al. 2008), recording of species presence (BERTRAND et al. 2006) and population monitoring (Mowat \& PaetKau 2002, De Barba et al. 2010). Therefore, we believe that, through proper improvements, this technique can prove to be useful for several kinds of studies on many species around the world.

\section{ACKNOWLEDGEMENTS}

We thank T. Margarido and N. Benavicius from Zoológico de Curitiba, P. Mangini and H. Chupil from Criadouro Conservacionista Onça-Pintada, and J. Pereira and C. Adania from Associação Mata Ciliar for their support to our study on their respective institutions. R. Miotto and E. Monteiro-Filho made substantial comments on an early draft of this manuscript, and N. Martins for her contribution. We are also thankful to Diego Astúa and three anonymous reviewers for their suggestions. This study was part of a master's thesis at the Programa de Pós-Graduação em Ecologia e Conservação, and received support from IAP and $\mathrm{CNPq}$ by means of the fellowship 135204/2009-7 to TPP. We also thank CAPES for the fellowship to DRB, and CNPq/MCT for provided funding to FCP (grant 300466/2009-9) and MRP (grant 571334/2008-3).

\section{LITERATURE CITED}

Aguiar, L.M. \& R.F. Moro-Rios. 2009. The direct observational method and possibilities for Neotropical Carnivores: an invitation for the rescue of a classical method spread over the Primatology. Zoologia 26 (4): 587-593.

Aguiar, L.M.; R.F. Moro-Rios; T. Silvestre; J.E. Silva-Pereira; D.R. Bilski; F.C. Passos; M.L. Sekiama \& V.J. Rocha. 2011. Diet of brown-nosed coatis and crab-eating raccoons from a mosaic landscape with exotic plantations in southern Brazil. Studies on Neotropical Fauna and Environment 46 (3): 153-161.

Becker, M. \& J.C. Dalponte. 1999. Rastros de mamíferos silvestres brasileiros. Brasília, Universidade de Brasília, 180p.

Bertrand, A-S.; S. Kenn; D. Gallant; E. Tremblay; L. Vasseur \& R. Wissink. 2006. MtDNA analyses on hair samples confirm cougar, Puma concolor, presence in southern New Brunswick, Eastern Canada. Canadian Field-Naturalist 120 (4): 438442.

Braga, F.G. \& G.P. Vidolin. 2010 Mamíferos Ameaçados no Paraná. Curitiba, IAP, 78p.

Bressan, M; M.K. Kierulff \& A.M. Sugieda. 2009. Fauna Ameaçada de Extinção no Estado de São Paulo. Vertebrados. São Paulo, Fundação Parque Zoológico de São Paulo, Secretaria do Meio Ambiente, 645p. 
CÁCeres, N.C. 2004. Occurrence of Conepatus chinga (Molina) (Mammalia, Carnivora, Mustelidae) and other terrestrial mammals in the Serra do Mar, Paraná, Brazil. Revista Brasileira de Zoologia 21 (3), 577-579.

Castro-Arellano, I.; C. Madrid-Luna; T.E. Lacher \& L. LéonPaniagua. 2008. Hair-Trap efficacy for detecting mammalian carnivores in the tropics. Journal of Wildlife Management 72: 1405-1412.

Crawshaw Jr, P.G. 1997. Recomendações para um modelo de pesquisa sobre felídeos neotropicais, p. 70-94. In: C. Valladares-Pádua \& R.E. Bodmer (Eds). Manejo e conservação de vida silvestre no Brasil. Belém, MCT, CNPq, Sociedade Civil Mamirauá.

De Barba, M.; L.P. Waits; E.O. Garton; P. Genovesi; E. Randi; A. Mustoni \& C. Groff. 2010. The power of genetic monitoring for studying demography, ecology and genetics of a reintroduced brown bear population. Molecular Ecology 19: 3938-3951.

Downey, P.J.; E.C. Hellgren; A. Caso; S. Carvajal \& K. Frangioso. 2007. Hair Snares for Noninvasive Sampling of Felids in North America: Do Gray Foxes Affect Success? Journal of Wildlife Management 71 (6): 2090-2094.

FACURE, K.G. \& E.L.A.Monteiro-Filho. 1996. Feeding habits of crabeating fox, Cerdocyon thous (Carnivora:Canidae), in a suburban area of southeastern Brazil. Mammalia 60 (1): 147-149.

Galetti, M.; H.C. Giacomini; R.S. Bueno; C.S.S. Bernardo; R.M. Marques; R.S. Bovendorp; C.E. Steffler; P. Rubim; S.K. Gobbo \& C.I. Donatri. 2009. Priority areas for the conservation of Atlantic forest large mammals. Biological Conservation 142: 1229-1241.

GitTleman, J.L. 1991. Carnivore olfactory bulb size: allometry, phylogeny and ecology. Journal of Zoology 225 (2): 253272.

HaRRISON, R.L.1997. Chemical attractants for Central American felids. Wildlife Society Bulletin 25: 93-97.

Heinemeyer, K.S.; T.J. Ulizio \& R.L. Harrison. 2008. Natural sign: tracks and scats, p. 45-74. In: R. Long; P. MacKaY; W. ZieLINSKI \& J.C. RAY (Eds). Noninvasive survey methods for carnivores. Washington, DC, Island Press.

IUCN. 2010. International Union for Conservation of Nature and Natural Resources. Avaliable online at: http:// www.iucnredlist.org. [Accessed: 12.II.2011].

Kendall, K.C. \& K.S. Mckelvey. 2008. Hair collection, p. 135176. In: R.A. LONG; P. MACKAY; W.J. ZieLINSKI \& J.C. RAY (Eds). Noninvasive survey methods for carnivores. Washington, DC, Island Press.

Leite, M.R.P. \& F. Galvão. 2002. El jaguar, el puma y el hombre en tres áreas protegidas del bosque atlántico costero de Paraná, Brasil, p. 237-250. In: R.A. Medellin; C. Chetкiewicz; A. Rabinowitz; K.H. Redford; J.G. Robinson; E. Sanderson \& A. Taber (Eds). El jaguar en el nuevo milenio. Mexico, Universidad Nacional Autonoma de Mexico, Wildlife Conservation Society.
Long, R.A.; T. Donovan; P. Mackay; W.J. Zielinski \& J.S. Buzas. 2007. Comparing scat detection dogs, cameras, and hair snares for surveying carnivores. Journal of Wildlife Management 71 (6): 2018-2025.

Long, R.A.; P. MackaY; W.J. ZielisnKI \& J.C. Ray 2008. Noninvasive survey methods for carnivores. Washington, DC, Island Press. 386p.

Ludwig, G; Malanski; M.M. Shiozawa; C.L.S. Hilst; I.T. Navarro \& F.C. PAssos. 2007. Cougar predation on Black-and-Gold Howlers on Mutum Island, Southern Brazil. International Journal of Primatology 28 (1): 39-46.

Machado, A.B.M.; G.M. Drummond \& A.P. Paglia. 2008. Livro Vermelho da Fauna Brasileira Ameaçada de Extinção. Belo Horizonte, Fundação Biodiversitas.

Marques, M.C.M.; M.D. Swaine \& D. Liebsch. 2011. Diversity distribution and floristic differentiation of the coastal lowland vegetation: implications for the conservation of the Brazilian Atlantic Forest. Biodiversity and Conservation 20 (1): 153-168.

Martins, R.; J. Quadros \& M. Mazzolli. 2008. Hábito alimentar e interferência antrópica na atividade de marcação territorial do Puma concolor e Leopardus pardalis (Carnivora:Felidae) e outros carnívoros na Estação Ecológica de Juréia-Itatins, São Paulo, Brasil. Revista Brasileira de Zoologia 25 (3): 427-435.

McDaniel, G.W.; K.S. McKelvey; J.R. SQuires \& L.F. Ruggiero. 2000. Efficacy of lures and hair snares to detect lynx. Wildlife Society Bulletin 28 (1): 119-123.

McKelvey, K.S.; J.V. Kienast; K.B. Aubry; G.M. Koehler; B.T. MaletZke; J.R. SQuires; E.L. Linquist; S. Loch \& M.K. SchwartZ. 2006. DNA analysis of hair and scat collected along snow tracks to document the presence of Canada lynx (Lynx canadensis). Wildlife Society Bulletin 34: 451-455.

McPhee, M.E. 2002. Intact carcasses as enrichment for large felids: effects on on-and off exhibit behaviors. Zoo Biology 21: 37-47.

Miotto, R.A.; G. Ciocheti; F.P. Rodrigues \& P.M. Galetti Jr. 2007. Identification of pumas (Puma concolor (Linnaeus, 1771)) through faeces: a comparison between morphological and molecular methods. Brazilian Journal of Biology 67 (4): 963-965.

Miotto, R.A.; M. Cervini; R.A. Begotti; P.M \& Galetti Jr. 2011. Monitoring a Puma (Puma concolor) Population in a Fragmented Landscape in Southeast Brazil. Biotropica 44 (1): 98-104. doi: 10.1111/j.1744-7429.2011.00772.x

Miranda, J.M.D.; I.P. Bernardi; K.C. Abreu \& F.C. Passos. 2005. Predation on Alouatta guariba clamitans Cabrera (Primates, Atelidae) by Leopardus pardalis (Linnaeus) (Carnivora, Felidae). Revista Brasileira de Zoologia 22 (3): 793-795.

Mowat, G. \& D. Peatkau. 2002. Estimating marten Martes americana population size using hair capture and genetic tagging. Wildlife Biology 8 (3): 201-209

OLIVEIRA, T.G. 2006. Research in terrestrial Carnivora from Brazil: current knowledge and priorities for the new Millennium, 
p. 39-45. In: R.G. Morato; F.H.G. Rodrigues; E. Eizirik; E. MAngini (Eds). Manejo e Conservação de Carnívoros Neotropicais. São Paulo, Ibama.

Quadros, J. \& E.L.A. Monteiro-Filho. 2006. Coleta e preparação de pêlos de mamíferos para identificação em microscopia óptica. Revista Brasileira de Zoologia 23 (1): 274-278.

Quadros, J. \& E.L.A. Monteiro-Filho. 2010. Identificação dos mamíferos de uma área de Floresta Atlântica utilizando a microestrutura de pelos-guarda de predadores e presas. Arquivos do Museu Nacional 68 (1, 2): 47-66.

ReED, S.E. 2011. Non-invasive Methods to Assess Co-Occurrence of Mammalian Canivores. The Southwestern Naturalist 56 (2): 231-240.

Ruell, W.W. \& K.R. Crooks. 2007. Evaluation of non-invasive genetic sampling methods for felid and canid populations. Journal of Wildlife Management 71: 1690-1694.

Sabbatini, G.; M. Stammati; M.C.H. Tavares \& E. Visalberghi. 2008. Behavioral flexibility of a group of bearded capuchin monkeys (Cebus libidinosus) in the National Park of Brasília (Brazil): consequences of cohabitation with visitors. Brazilian Journal of Biology 68 (4): 685-693.

Schlexer, F.V. 2008. Attracting Animals to Detection Devices, p. 263-292. In: R.A. LONG; P. MACKAY; W.J. ZIELINSKI \& J.C. RAY (Eds). Noninvasive survey methods for carnivores. Washington, DC, Island Press.

SEMA-IAP. 1996. Plano de Manejo do Parque Estadual do Pico do Marumbi - PR. Curitiba, Secretaria de Estado do Meio Ambiente-Instituto Ambiental do Paraná,114p.
Silva-Pereira, J.E.; R.F. Moro-Rios; D.R. Bilski \& F.C. Passos. 2011. Diets of three sympatric Neotropical small cats: Food niche overlap and interspecies differences in prey consumption. Mammalian Biology 76 (3): 308-312.

Tanás, L. \& W. PIsula. 2011. Response to novel object in Wistar and Wild-type (WWCPS) rats. Behavioural Processes 86 (2011): 279-283.

Thomas, P.; G. Balme; L. Hunter \& J. McCabe-Parodi. 2005. Using scent attractants to non-invasively collect hair samples from cheetahs, leopards and lions. Animal Keeper's Forum 7 (8): 342-384.

Tomas, W.M.; F.H.G. Rodrigues \& R. Fusco-Costa. 2006. Levantamento e monitoramento de populações de carnívoros, p. 145-167. In: R.G. Morato; F.H.G. Rodrigues; E. Eizirik; P.R. Mangini; F.C.C. Azevedo \& J. Marinho-Filho (Eds). Manejo e Conservação de Carnívoros Neotropicais. Brasília, IBAMA.

Wasser, S.K.; B.E.R. Davenport; K. Ramage, E. Hunt; M. Parker, C. Clarke \& G. Stenhouse. 2004. Scat detection dogs in wildlife research and management: application to grizzly and black bears in the Yellowhead Ecosystem, Alberta, Canada. Canadian Journal of Zoology 82 (3): 475-492.

Weaver, J.L.; P. Wood; D. Paetkau \& L.L. Laack. 2005. Use of scented hair snares to detect ocelots. Wildlife Society Bulletin 33: 1384-1391.

Weller, S.H. \& C.L. BennetT. 2001. Twenty-four hour activity budgets and patterns of behaviour in captive ocelots (Leopardus pardalis) Applied Animal Behaviour Science 71: 67-69.

Submitted: 03.IV.2012; Accepted: 13.IX.2012.

Editorial responsibility: Diego Astúa de Moraes 